\title{
PENGARUH KEMAMPUAN OPERASI HITUNG TERHADAP KEMAMPUAN PEMECAHAN MASALAH MATEMATIKA
}

\author{
Suwarto ${ }^{1}$ \\ Wahyu Hidayat ${ }^{2}$ \\ Dosen STMIK Raharja Tangerang Jurusan Sistem Informasi, ${ }^{1,2}$ \\ Jl. Jendral Sudirman No 40 Modern Cikokol, Tangerang ${ }^{1,2}$ \\ Email : suwarto@ raharja.info $^{1}$,wahyu@ raharja.info
}

\begin{abstract}
ABSTRAK
Penelitian ini betujuan untuk mengetahuan sejauh mana kemampuan operasi hitung siswa SMK Negeri 2 Kabupaten Tangerang, sejauh mana kemampuan pemecahan masalah matematika SMK Negeri 2 Kabupaten Tangerang dan pengaruh keampuan operasi hitung terhadap kemampuan pemecahan masalah matematika siswa SMK SMK Negeri 2 Kabupaten Tangerang. Hasil dari penelitian ini adalah kemampuan operasi hitung siswa SMK Negeri 2 Kabupaten Tangerang, berada pada katagori sedang, dengan nilai rerata 54,59 terletak pada rentang 50,17< $\bar{x} \leq 55,83$. Kemampuan pemecahan masalah matematika SMK Negeri 2 Kabupaten Tangerang berada pada katagori tinggi, dengan nilai rerata 10 terletak pada rentang 9,58 $<\bar{x} \leq 11,75$. Tidak terdapat pengaruh yang signifikan variabel bebas $X$ (kemampan operasi hitung) terhadap variabel terikat $Y$ (kemampuan pemecahan masalah matematika) hal ini terlihat pada nilai sig table ANOVA sebesar 0,721 lebih besar dari 0,05. Kata kunci: operasi hitung, pemecahan masalah matematika, sig.
\end{abstract}

\section{PENDAHULUAN}

Menurut Howard Gardner yang dikutip oleh Bruce Campbell, kecerdasan adalah kemampuan untuk menyelesaikan masalah yang terjadi dalam kehidupan manusia, kemampuan untuk menghasilkan persoalan-persoalan baru untuk diselesaikan, dan kemampuan untuk menciptakan sesuatu atau menawarkan jasa yang akan menimbulkan penghargaan dalam budaya seseorang[1].

Kemampuan siswa dalam memecahkan masalah menjadi bagian yang perlu dikaji dalam penelitian ini disebabkan masih banyak siswa ketika belajar hanya mampu menghasilkan secara teoritik yang diberikan oleh pengajar tanpa mampu mengkaji dan memecahkan masalah yang berkaitan dengan pelajaran dalam kehidupan nyata. Belajar yang penuh makna terutama dalam hal ini adalah belajar matematika, siswa harus mampu menterjemahkannya dalam kehidupan nyata, atau aplikasinya dalam kehidupan sehari-hari, hal ini membutuhkan kemampuan pemecahan masalah matematika harus senantiasa diasah.

Kemapuan pemecahan masalah dalam pelajaran matematika dipengaruhi oleh kemampuan operasi hitung, mengapa? Sebab kemampuan operasi hitung merupakan dasar dari penarikan dalil-dalil, teorima, definisi dan lain-lain guna pembuktiannya. Suatu hal yang menjadikan dasar yang perlu menjadikan penarikan kesimpulan dalam operasi hitung, semisal penjumlah adalah pokok dari semua operasi, sebab dari penjumlahan dapat menurunkan pengurangan, dapat menurunkan perkalian dan dari perkalian dapat menurunkan pembagian. 
Kemampuan pemecahan masalah jika setiap siswa mampu untuk melakukaanya, terutama dalam kaitannya pelajaran matematika sangatlah penting untuk dikuasai oleh siswa. Sehingga belajaran matematika akan bermakna artinya belajar matematika akan tahu penggunaanya di kehidupan sehari-hari. Akan tetapi masih banyak siswa jika menyelesaikan yang terkait soal terapan agak sulit untuk dapat menyelesaikannya, ini dimungkinkan karena mengidentifikasi masalah yang terkait dengan matematika masih sangat kurang.

Pelaksanaan evaluasi pada tingkat akhir setiap jenjang pendidikan dasar, menengah ataupun atas yang dikenal Ujian Akhir Nasional ( UAN ), menjadikan siswa ataupun guru hanya mengejar hasil akhir atau nilai saja tanpa mempertimbangkan proses bagaimana penyelesaian soal itu dilaksanakan. Hal ini juga yang menambah pola pikir siswa bahwa nilai lebih penting dari pada sekendar bisa terlebih menguasai materi. Jelas jika ini terjadi siswa akan lebih jauh dari kemampuan bagaimana pemecahan masalah terkait matematika.

Obyek yang dijadikan kajian adalah siswa SMK Negeri 2 Kabupaten Tangerang pada kelas 12 jurusan Teknik Komputer Jaringan, sebab setingkat siswa SMK sudah mulai berkembang cara berpikir dan kemudian cara memecahkan masalahnya sendiri.

\section{RUMUSAN MASALAH}

Dalam penelitian ini rumusan masalah yang di ajukan sebagai berikut:

1. Sejauh mana kemampuan operasi hitung siswa SMK Negeri 2 Kabupaten Tangerang?

2. Sejauh mana kemampuan pemecahan masalah matematika SMK Negeri 2 Kabupaten Tangerang?

3. Apakah terdapat pengaruh keampuan operasi hitung terhadap kemampuan pemecahan masalah matematika siswa SMK SMK Negeri 2 Kabupaten Tangerang?

\section{KAJIAN TEORI}

\section{a. Kemampuan operasi hitung}

Pokok dari semua operasi adalah penjumlah, dari penjumlahan dapat menurunkan pengurangan, dari peniumlahan dapat menrunkan konsep perkalian, dari pengurangan dapat menurunkan konsep pembagian, dari perkalian dapat menurunkan bentuk akar, dari perkalian dapat menurunkan bentuk logaritma. Awal mula operasi hitung adalah penjumlahan.

Kemampuan, kecakapan, ketangkasan, bakat, kesanggupan merupakan tenaga (daya kekuatan) untuk melakukan suatu perbuatan. Kecakapan atau potensi menguasai suatu keahlian yang merupakan bawaan sejak lahir atau merupakan hasil latihan atau praktek dan digunakan untuk melakukan suatu perbuatan[2].

Menghitung: 1) mencari jumlahnya (sisanya, pendapatannya) dengan menjumlahkan, mengurangi dan sebagainya, 2) membilang untuk mengetahui berapa jumlahnya, banyaknya)[3]. Kemampuan menghitung merupakan salah satu kemampuan yang penting dalam kehidupan sehari-hari. Semua aktivitas kehidupan manusia memerlukan kemampuan ini. Kemampuan menghitung merupakan bagian yang penting dalam menggunakan strategi untuk menyelesaikan soal-soal pemecahan masalah. Hampir semua strategi pemecahan masalah matematika menuntut kemampuan menghitung, karena soal-soal pemecahan 
matematika pada umumnya didominasi oleh soal-soal hitungan matematika. Contoh: siswa menghitung garis tengah yang diperlukan untuk keliling suatu lingkaran, siswa menghitung penjumlahan bilangan bulat.

Kata keterampilan memiliki arti yang sama dengan kecekatan. Keterampilan atau kecekatan adalah kepandaian melakukan suatu pekerjaan dengan cepat dan benar[4]. Seseorang yang dapat melakukan sesuatu dengan cepat tetapi salah atau melakukan sesuatu dengan benar tetapi lambat, tidak dapat dikatakan terampil. Seseorang yang terampil dalam suatu bidang tidak ragu-ragu melakukan pekerjaan dalam bidang tersebut, seakan-akan tidak dipikirkan lagi bagaimana melaksanakannya, dan tidak ada kesulitankesulitan yang menghambat. Keterampilan dapat diperoleh dengan cara berlatih terus menerus dan berulangulang. Keterampilan sering diartikan sebagai sesuatu yang berkaitan dengan pekerjaan fisik, padahal keterampilan lebih luas lagi cakupannya. Selain pekerjaan fisik, keterampilan juga mencakup pekerjaan non fisik seperti berfikir. Keterampilan fisik misalnya seseorang yang cekat dalam membuat kerajinan. Keterampilan yang berkaitan dengan berfikir salah satunya adalah cekat dalam melakukan operasi hitung pada mata pelajaran matematika. Jika seseorang dapat melakukan operasi hitung dengan cekatan, maka dapatdikatakan terampil.

Keterampilan operasi hitung merupakan salah satu kemampuan yang penting dalam kehidupan sehari-hari dan dapat menunjang cara berfikir yang cepat, tepat dan cermat. Keterampilan ini sangat mendukung siswa untuk memahami simbol-simbol dalam matematika[5]. Matematika adalah mata pelajaran yang sangat erat kaitannya dengan operasi hitung. Hampir dalam setiap materi matematika selalu menggunakan operasi hitung. Hal ini berarti bahwa keterampilan operasi hitung menjadi bagian yang sangat penting dalam matematika dan mutlak diperlukan agar siswa dapat belajar matematika dengan baik termasuk bagi siswa kelas V SD. Jika keterampilan ini belum dikuasai dengan baik, maka pembelajaran matematika akan terhambat. Contohnya adalah jika siswa tidak dapat mengalikan dengan baik, maka materi tentang operasi hitung bilangan bulat juga tidak akan dapat dikuasai dengan baik.

Kata keterampilan memiliki arti yang sama dengan kecekatan. Keterampilan atau kecekatan adalah kepandaian melakukan suatu pekerjaan dengan cepat dan benar. Seseorang yang dapat melakukan sesuatu dengan cepat tetapi salah atau melakukan sesuatu dengan benar tetapi lambat, tidak dapat dikatakan terampil. Seseorang yang terampil dalam suatu bidang tidak ragu-ragu melakukan pekerjaan dalam bidang tersebut, seakan-akan tidak dipikirkan lagi bagaimana melaksanakannya, dan tidak ada kesulitan-kesulitan yang menghambat. Keterampilan dapat diperoleh dengan cara berlatih terus menerus dan berulangulang.

Keterampilan sering diartikan sebagai sesuatu yang berkaitan dengan pekerjaan fisik, padahal keterampilan lebih luas lagi cakupannya. Selain pekerjaan fisik, keterampilan juga mencakup pekerjaan non fisik seperti berfikir. Keterampilan fisik misalnya seseorang yang cekat dalam membuat kerajinan. Keterampilan yang berkaitan dengan berfikir salah satunya adalah cekat dalam melakukan operasi hitung pada mata pelajaran matematika. Jika seseorang dapat melakukan operasi hitung dengan cekatan, maka dapat dikatakan terampil.

Ada beberapa operasi hitung yang dapat dikenakan pada bilangan. Operasi-operasi tersebut adalah: (1) penjumlahan; (2) pengurangan; (3)perkalian; (4) pembagian. Operasioperasi tersebut memiliki kaitan yang sangat erat sehingga pemahaman konsep dan keterampilan melakukan operasi yang satu akan mempengaruhi pemahaman konsep dan keterampilan operasi yang lain. 
Operasi penjumlahan pada dasarnya merupakan suatu aturan yang mengaitkan setiap pasang bilangan dengan bilangan yang lain. Operasi penjumlahan ini mempunyai beberapa sifat yaitu: sifat pertukaran (komutatif), sifat identitas, dan sifat pengelompokan (asosiatif).

Operasi pengurangan merupakan kebalikan dari operasi penjumlahan, tetapi operasi pengurangan tidak memiliki sifat yang dimiliki operasi penjumlahan. Operasi pengurangan tidak memenuhi sifat pertukaran, sifat identitas, dan sifat pengelompokan.

Operasi perkalian dapat didefinisikan sebagai penjumlahan berulang. Misalkan pada perkalian 4 x 3 dapat didefinisikan sebagai $3+3+3+3=12$ sedangkan $3 \times 4$ dapat didefinisikan sebagai $4+4+4=12$. Secara konseptual, $4 \times 3$ tidak sama dengan $3 \times 4$, tetapi jika dilihat hasilnya saja maka $4 \times 3=3 \times 4$. Dengan demikian operasi perkalian memenuhi sifat pertukaran.

Operasi perkalian memenuhi sifat identitas. Ada sebuah bilangan yang jika dikalikan dengan setiap bilangan, maka hasilnya tetap bilangan itu sendiri. Bilangan tersebut adalah 1 . Jadi jika a x $1=$ a. Operasi perkalian juga memenuhi sifat pengelompokan. Untuk setiap bilangan a, b, dan c berlaku: ( $\mathrm{a}$ b) x c = a x (b x c). Misalkan untuk operasi bilangan cacah $(2 \times 3) \times 4=2 \times(3 \times 4)$. Selain sifat-sifat tersebut, operasi perkalian masih mempunyai satu sifat yang berkaitan dengan operasi penjumlahan. Sifat ini menyatakan untuk bilangan $a, b$, dan c berlaku: $a \times(b+c)=(a \times b)+(a \times c)$. Sifat ini disebut dengan sifat penyebaran atau distributif.

Operasi pembagian dapat didefinisikan sebagai pengurangan berulang. Secara matematis ditulis sebagai $\mathrm{a}: \mathrm{b}=\mathrm{a}-\mathrm{b}-\mathrm{b}-\mathrm{b} \ldots . .=0$. Misal, $24: 3=24-3-3-3-3-3-3-3-3$ $=0$. Berarti $24: 3=8$. Hasil ini ditunjukkan oleh banyaknya angka 3 yang muncul sebagai bilangan pengurangnya. Operasi pembagian adalah kebalikan dari operasi perkalian. Jika sebuah bilangan a dibagi bilangan $\mathrm{b}$ menghasilkan bilangan $\mathrm{c}$ (dilambangkan dengan $\mathrm{a}: \mathrm{b}=$ c), maka konsep perkalian yang terkait adalah $\mathrm{c} \mathrm{x} \mathrm{b}=\mathrm{a}$. Operasi pembagian memiliki sifat sebagaimana operasi pengurangan yaitu tidak memenuhi sifat pertukaran, sifat identitas, dan sifat pengelompokan. Operasi pembagian tidak memenuhi sifat pertukaran.

Peta konsep atau hirarki dari operasi hitung dapat terlihat pada gambar berikut:

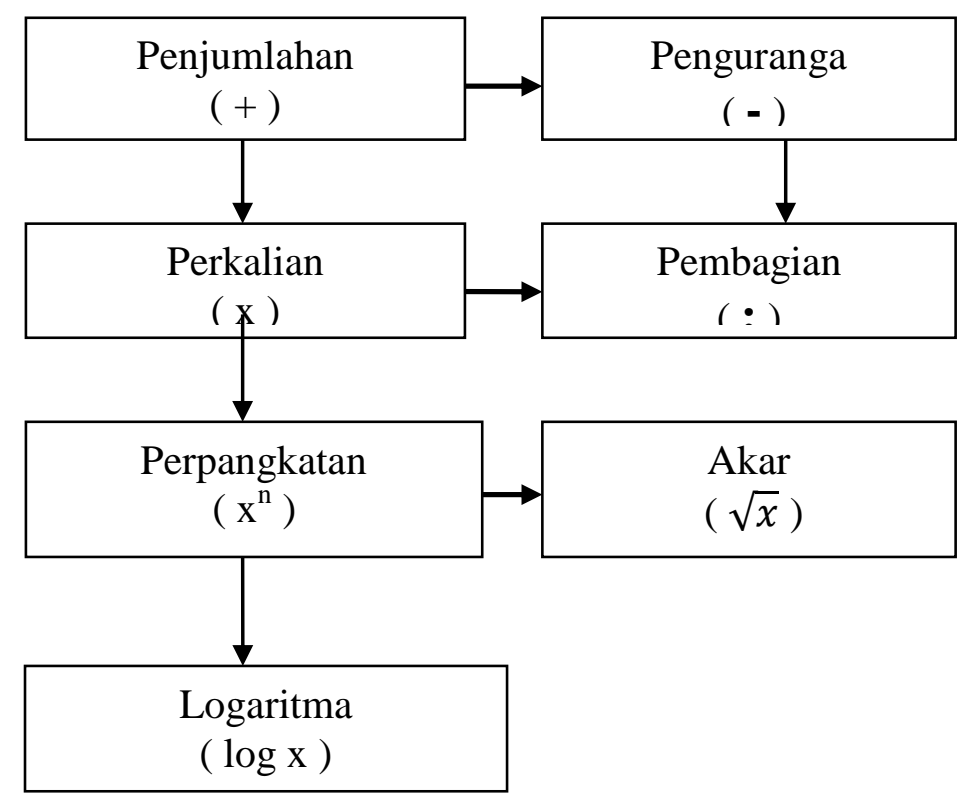


Operasi hitung harus dikuasai oleh siswa sampai dengan taraf terampil. Keterampilan operasi hitung merupakan modal utama dalam pembelajaran matematika. Keterampilan operasi hitung harus dikuasai siswa agar pembelajaran matematika dapat berjalan dengan baik.

Seseorang yang tidak dapat menghitung dengan benar, berarti dia tidak memiliki keterampilan operasi hitung. Seseorang yang dapat melakukan operasi hitung tetapi membutuhkan waktu lama, juga tidak dapat dianggap terampil dalam operasi hitung. Keterampilan operasi hitung memuat dua hal utama yaitu kecepatan dan ketepatan dalam melakukan operasi hitung.

Keterampilan operasi hitung merupakan salah satu kemampuan yang penting dalam kehidupan sehari-hari dan dapat menunjang cara berfikir yang cepat, tepat dan cermat. Keterampilan ini sangat mendukung siswa untuk memahami simbol-simbol dalam matematika. Kemampuan operasi hitung adalah suatu keterampilan yang dimiliki seseorang yang mampu menyelesaikan operasi penjumlahan, pengungaran, perkalian, pembagian, bentuk pangkat, bentuk akar ataupun bentuk logaritma yang dilakukan dalam kehidupan sehari-hari dan dapat menunjang cara berfikir secara cermat dan tepat.

\section{b. Kemampuan pemecahan masalah matematika}

Penalaran dan pemecahan masalah merupakan bagian yang sangat penting dalam belajar matematika, karena matematika terbentuk dan berkembang melalui proses penalaran dan pemecahan masalah. Kemampuan penalaran dan pemecahan masalah matematika perlu dimiliki para siswa dari jenjang sekolah dasar hingga sekolah menengah. Matematika berfungsi untuk mengembangkan kemampuan bernalar melalui kegiatan penyelidikan, eksplorasi dan eksperimen sebagai alat pemecahan masalah melalui pola pikir dan model matematika, serta sebagai alat komunikasi melalui simbol, tabel, grafik diagram dalam menjelaskan gagasan. Lebih lanjut disebutkan bahwa pembelajaran matematika menuntut kemahiran matematika yang mencakup antara lain penalaran dan pemecahan masalah.

Sebagian besar ahli Pendidikan Matematika menyatakan bahwa masalah merupakan pertanyaan yang harus dijawab atau direspon. Namun mereka juga menyatakan juga bahwa tidak semua pertanyaan otomatis menjadi masalah. Suatu pertanyaan akan menjadi masalah hanya jika pertanyaan itu menunjukkan adanya suatu tantangan yang tidak dapat dipecahkan oleh suatu prosedur rutin yang sudah diketahui pelaku. Definisi di atas berimplikasi bahwa termuatnya tantangan serta belum diketahuinya prosedur rutin pada suatu pertanyaan menjadi masalah atau hanyalah suatu pertanyaan biasa. Oleh karena itu dapat terjadi bahwa suatu masalah bagi seorang siswa akan menjadi pertanyaan bagi siswa lainnya karena ia sudah mengetahui prosedur untuk menyelesaikannya. Sebagai contoh, menentukan nilai 1234 x 4 tidak dapat dikategorikan sebagai suatu masalah bagi siswa sekolah menengah karena mereka telah mengetahui prosedur penyelesaiannya.

Pemecahan masalah berarti seseorang menggunakan pengetahuan, keterampilan dan pemahaman yang telah diperoleh sebelumnya untuk memenuhi permintaan dari situasi yang tidak biasa. Pemecahan masalah merupakan kunci dari seluruh aspek matematika. Dalam proses pembelajaran matematika, pemecahan masalah matematika merupakan suatu pendekatan pembelajaran yang digunakan untuk menemukan dan memahami materi/konsep matematika [6].

Menurut Francis A. Adejosi "The results of the study has, however, indicated that students could be better problem-solvers if they are of high ability level, but, those with low ability could also perfect their problemsolving skills if they are exposed to problem-solving 
instructional strategy". Berdasarkan jurnal international tersebut dapat dijelaskan bahwa siswa bisa lebih baik dalam pemecahan masalah jika mereka dari tingkat kemampuan yang tinggi, tetapi siswa yang memiliki kemampuan rendah juga bisa sempurna keterampilan memecahkan masalah bila mereka dihadapkan dengan strategi pembelajaran pemecahan masalah. Ini berarti semua siswa memilki keterampilan memecahkan masalah sempurna apabila dihadapkan dengan strategi pembelajaran yang tepat.

Pemecahan masalah matematika adalah suatu kegiatan manusia yang menggabungkan konsep-konsep dan aturan-aturan yang telah diperoleh sebelumnya dalam menyelesaikan suatu persoalan yang terkait dengan bernalar, menduga atau memprediksikan, mencari rumusan yang dinyatakan dalam angka-angka atau simbol-simbol[7].

\section{METODOLOGI PENELITIAN}

Penelitian ini direncanakan bertempat SMK Negeri 2 Kabupaten, metode yang digunakan dalam penelitian ini adalah metode survey dengan teknik korelasional. Metode ini memberikan deskripsi tentang variabel yang akan diteliti dan menyelidiki hubungan antar variabel, hubungan kemampuan operasi hitung terhdap kemampuan pemecahan masalah matematika.

Teknik pengumpulan data kemampuan pemecahan masalah matematika dan kemampuan operasi hitung dalam penelitian ini yaitu dengan cara menyebarkan instrumen kemampuan pemecahan masalah matematika dan kemampuan operasi hitung pada sampel yang telah ditentukan. Skor kemampuan pemecahan masalah matematika dan kemampuan operasi hitung diperoleh dengan menggunakan instrumen kemampuan pemecahan masalah matematika dan kemampuan operasi hitung yang telah melalui pembakuan instrumen yakni validitas, reabilitas, tingkat kesukaran dan dan daya pembeda.

Pengaruh kemampuan operasi hitung terhadap kemampuan pemecahan masalah matematika, hipotesis yang diajukan sebagai berikut:

Ho: $\beta_{\mathrm{y}}=0$

$\mathrm{H}_{1} \beta_{\mathrm{y}} \neq 0$

Keterangan:

Ho : tidak terdapat pengaruh yang signifikan kemampuan operasi hitung terhadap kemampuan pemecahan masalah matematika.

H1: terdapat pengaruh yang signifikan kemampuan operasi hitung terhadap kemampuan pemecahan masalah matematika.

Untuk membuktikan hipotesis tersebut adalah dengan memperhatikan nilai/bilangan yang tertera pada kolom Sig untuk baris kemampuan operasi hitung (Variabel X) pada Tabel ANAVA. Menurut ketentuan yang ada, kriteria signifikansi regresi tersebut adalah "jika Sig < 0,05 maka $\mathrm{H}_{0}$ ditolak", yang berarti bahwa terdapat pengaruh yang signifikan variabel bebas $\mathrm{X}$ terhadap variabel terikat Y. Nilai Sig adalah bilangan yang tertera pada kolom Sig untuk baris kemampuan operasi hitung (Variabel X) dalam Tabel ANAVA[8].

\section{HASIL PENELITIAN}

Data tentang kemamapuan pemecahan masalah yang dihasilkan dari tes yang dilakukan pada siswa kelas XI Sekolah Menengah Kejuruan (SMK) Negeri 2 Kabupaten Tangerang yang berjumlah 101, setelah dilakukan perhitungan dengan menggunakan bantuan SPSS 
Versi 20.0 guna mengetahuan ukuran pemusatan data yang meliputi skor minimum, skor maksimum, rerata, standar deviasi, modus dan median.

Hasil perhitungan diskripsi data yang dibantu dengan program SPSS versi 20.00 terlihat pada tabel berikut:

Tabel 1. Ukuran pemusatan data kemampauan pemecahan masalah matematika

\begin{tabular}{|c|c|c|}
\hline \multicolumn{3}{|c|}{ Statistics } \\
\hline \multicolumn{3}{|c|}{ Kemampuan Pemecahan Masalah Matematika } \\
\hline \multirow{2}{*}{$\mathrm{N}$} & Valid & 101 \\
\hline & Missing & $\mathbf{0}$ \\
\hline \multicolumn{2}{|c|}{ Mean } & 54.59 \\
\hline \multicolumn{2}{|c|}{ Median } & 56.00 \\
\hline \multicolumn{2}{|c|}{ Mode } & 56 \\
\hline \multicolumn{2}{|c|}{ Std. Deviation } & 8.266 \\
\hline \multicolumn{2}{|c|}{ Variance } & 68.324 \\
\hline \multicolumn{2}{|c|}{ Range } & 34 \\
\hline \multicolumn{2}{|c|}{ Minimum } & 36 \\
\hline \multicolumn{2}{|c|}{ Maximum } & $\mathbf{7 0}$ \\
\hline \multicolumn{2}{|c|}{ Sum } & 5514 \\
\hline
\end{tabular}

Untuk mendapatkan gambaran tentang kecenderungan kemampuan pemecahan masalah matematika siswa kelas XI Sekolah Menengah Kejuruan (SMK) Negeri Se-Gugus 06 Kabupaten Tangerang dengan mengkatagorikan nilai rerata observasi terhadap pedoman skala lima. Sebelumnya ditentukan terlebih dahulu rerata ideal (Mi) dan standar Deviasi ideal (SDi)[9].

$\operatorname{Mi}($ rerata ideal $)=\frac{1}{2}(70+36)=53,00$

SDi $($ standar deviasi ideal $)=\frac{1}{6}(70-36)=5,67$

Jadi didapat pedoman konversi skala lima untuk data tentang kemampuan pemecahan masalah matematika, sebagai berikut:

$$
\begin{array}{ll}
\bar{x}>61,50 & =\text { sangat tinggi } \\
55,83<\bar{x} \leq 61,50 & =\text { tinggi } \\
50,17<\bar{x} \leq 55,83 & =\text { sedang } \\
44,50<\bar{x} \leq 50,17 & =\text { rendah } \\
\bar{x} \leq 44,50 & =\text { sangat rendah }
\end{array}
$$

Dengan memperhatikan rerata skor kemampuan pemecahan masalah matematika yang bernilai 54,59 dan pedoman koversi skala lima, maka terlihat rerata tersebut terletak pada rentang $50,17<\bar{x} \leq 55,83$. Ini mengindikasikan bahwa kemampuan pemecahan masalah matematika siswa-siswa Sekolah Menengah Kejuruan Negeri Se-gugus 06 Kabupaten Tangerang pada katagori sedang.

Data tentang kemamapuan operasi hitung yang dihasilkan dari tes yang dilakukan pada siswa kelas XI Sekolah Menengah Kejuruan (SMK) Negeri Se-Gugus 06 Kabupaten Tangerang yang berjumlah 101, setelah dilakukan perhitungan dengan menggunakan bantuan 
SPSS Versi 20.0 guna mengetahuan ukuran pemusatan data yang meliputi skor minimum, skor maksimum, rerata, standar deviasi, modus dan median.

Adapun hasil perhitungannya terlihat pada tabel berikut:

Tabel 2. Ukuran pemusatan data kemampauan operasi hitung

\begin{tabular}{|c|c|c|}
\hline \multicolumn{3}{|c|}{$\begin{array}{ll}\text { Statistics } \\
\end{array}$} \\
\hline \multicolumn{3}{|c|}{ Kemampuan Operasi Hitung } \\
\hline \multirow{2}{*}{$\mathrm{N}$} & Valid & 101 \\
\hline & Missing & $\mathbf{0}$ \\
\hline \multicolumn{2}{|c|}{ Mean } & 10.00 \\
\hline \multicolumn{2}{|c|}{ Median } & 10.00 \\
\hline \multicolumn{2}{|c|}{ Mode } & $9^{\mathrm{a}}$ \\
\hline \multicolumn{2}{|c|}{ Std. Deviation } & $\mathbf{3 . 0 3 6}$ \\
\hline \multicolumn{2}{|c|}{ Variance } & 9.220 \\
\hline \multicolumn{2}{|c|}{ Range } & 13 \\
\hline \multicolumn{2}{|c|}{ Minimum } & 2 \\
\hline \multicolumn{2}{|c|}{ Maximum } & 15 \\
\hline \multicolumn{2}{|c|}{ Sum } & 1010 \\
\hline
\end{tabular}

Untuk mendapatkan gambaran tentang kecenderungan kemampuan operasi hitung siswa kelas XI Sekolah Menengah Kejuruan (SMK) Negeri Se-Gugus 06 Kabupaten Tangerang dengan mengkatagorikan nilai rerata observasi terhadap pedoman skala lima. Sebelumnya ditentukan terlebih dahulu rerata ideal (Mi) dan standar Deviasi ideal (SDi).

Mi $($ rerata ideal $)=\frac{1}{2}(15+2)=8,5$

SDi $($ standar deviasi ideal $)=\frac{1}{6}(15-2)=2,17$

Jadi didapat pedoman konversi skala lima untuk data tentang kemampuan pemecahan masalah matematika, sebagai berikut:

$$
\begin{array}{ll}
\bar{x}>11,75 & \text { = sangat tinggi } \\
9,58<\bar{x} \leq 11,75 & =\text { tinggi } \\
7,42<\bar{x} \leq 9,58 & =\text { sedang } \\
5,25<\bar{x} \leq 7,42 & =\text { rendah } \\
\bar{x} \leq 5,25 & =\text { sangat rendah }
\end{array}
$$

Dengan memperhatikan rerata skor kemampuan operasi hitung yang bernilai 10 dan pedoman koversi skala lima, maka terlihat rerata tersebut terletak pada rentang $\quad 9,58<\bar{x}$ $\leq 11,75$. Ini mengindikasikan bahwa kemampuan pemecahan masalah matematika siswasiswa Sekolah Menengah Kejuruan Negeri Se-gugus 06 Kabupaten Tangerang pada katagori tinggi. 
Tabel 3. ANOVA

\begin{tabular}{|c|c|c|c|c|c|c|}
\hline \multicolumn{7}{|c|}{ ANOVA $^{\mathbf{a}}$} \\
\hline \multicolumn{2}{|c|}{ Model } & $\begin{array}{l}\text { Sum of } \\
\text { Squares }\end{array}$ & df & $\begin{array}{l}\text { Mean } \\
\text { Square }\end{array}$ & $\mathrm{F}$ & \\
\hline \multirow{3}{*}{1} & Regression & $\mathbf{3 . 4 0 1}$ & 1 & 3.401 & 0,129 & $0,721^{b}$ \\
\hline & Residual & 2619.648 & 99 & 26.461 & & \\
\hline & Total & 2623.050 & 100 & & & \\
\hline \multicolumn{7}{|c|}{ a. Dependent Variable: Kemampuan Pemecahan Masalah Matematika } \\
\hline \multicolumn{7}{|c|}{ b. Predictors: (Constant), Kemampuan Operasi Hitung } \\
\hline
\end{tabular}

Dari terlihat bahwa nilai Sig $=0,721$. Karena nilai Sig=0,721 >0,05 maka $\mathrm{H}_{0}$ diterima yang berarti tidak terdapat pengaruh yang signifikan variabel bebas $\mathrm{X}$ (kemampuan operasi hitung) terhadap variabel terikat Y (kemampuan pemecahan masalah matematika).

Dari hasil pengujian regresi tersebut maka bisa disimpulkan bahwa tidak terdapat pengaruh yang signifikan variabel bebas $X$ (kemampuan operasi hitung) terhadap variabel terikat Y (kemampuan pemecahan masalah matematika).

\section{KESIMPULAN}

Kemampuan operasi hitung siswa SMK Negeri 2 Kabupaten Tangerang, berada pada katagori sedang, dengan nilai rerata 54,59 terletak pada rentang 50,17< $\bar{x} \leq 55,83$. Kemampuan pemecahan masalah matematika SMK Negeri 2 Kabupaten Tangerang berada pada katagori tinggi, dengan nilai rerata 10 terletak pada rentang 9,58 $<\bar{x} \leq 11,75$. Dengan melihat hasil pengujian regresi tersebut maka bisa disimpulkan bahwa tidak terdapat pengaruh yang signifikan variabel bebas $\mathrm{X}$ (kemampan operasi hitung) terhadap variabel terikat $\mathrm{Y}$ (kemampuan pemecahan masalah matematika).

\section{DAFTAR PUSTAKA}

[1] Campbell, Bruce, Linda Campbell dan Dee Dickinson, "Metode Praktis Pembelajaran Berbasis Multiple Intelligences, ”. Intuisi Press. Depok, pp.12, April. 2006.

[2] Soehardi, Esensi Perilalu Organisasional. Bagian Penerbit Fakultas Ekonomi Sarjanawiyata Tamansiswa, Yogyakarta, pp24, Februari 2003.

[3] Ruseffendi, E.T. Pengantar Kepada Membantu Guru mengembangkan kompetensinya Dalam pengajaran Matamatika. Tarsito, Bandung, pp12, Maret 1988.

[4] Djaali. Psikologi Pendidikan. Bumi Aksara. Jakarta, pp20, September 2008.

[5] Hasibuan, J.J., dan Moedjiono. Proses Belajar Mengajar. Remadja,Bandung. pp36.

[6] Meier, Dave. The Accelerated Learning Hand Book. Kaifa, Bandung, pp 65. Maret. 2002.

[7] Nasution, S. Berbagai Pendekatan dalam Proses Belajar. Bumi Aksara, Jakarta, pp54, Januari. 2008.

[8] Sutrisno Hadi,.Statistik Jilid 2. Andi Yogyakarta, Yogyakarta, pp 80, Oktober. 2000

[9] Sudijono, Anas.. Pengantar Evaluasi Pendidikan. Grafindo Persada, Jakarta, pp102, Maret, 2006

[10] S.Margono. Metodologi Penelitian Pendidikan. Reneka Cipta, Jakarta, pp 100, April.2007.

[11] Suharsimi Arikunto. Manajemen Penelitian. Rineka Cipta, Jakarta, pp76. September. 2009.

[12] Sudjana. Metoda Statistika. Penerbit Tarsito, Bandung, pp67, Oktober.2005 